University of Nebraska - Lincoln

DigitalCommons@University of Nebraska - Lincoln

Faculty Papers and Publications in Animal

Science

Animal Science Department

2009

\title{
Influence of Corn Hybrid and Processing Method on Nutrient Digestibility, Finishing Performance, and Carcass Characteristics
}

\author{
F. W. Harrelson \\ University of Nebraska-Lincoln \\ Matt K. Luebbe \\ University of Nebraska - Lincoln, mluebbe2@unl.edu \\ N. F. Meyer \\ University of Nebraska-Lincoln \\ Galen E. Erickson \\ University of Nebraska-Lincoln, gerickson4@unl.edu \\ Terry J. Klopfenstein \\ University of Nebraska-Lincoln, tklopfenstein1@unl.edu \\ See next page for additional authors
}

Follow this and additional works at: https://digitalcommons.unl.edu/animalscifacpub

Part of the Animal Sciences Commons

Harrelson, F. W.; Luebbe, Matt K.; Meyer, N. F.; Erickson, Galen E.; Klopfenstein, Terry J.; Jackson, David S.; and Fithian, W. A., "Influence of Corn Hybrid and Processing Method on Nutrient Digestibility, Finishing Performance, and Carcass Characteristics" (2009). Faculty Papers and Publications in Animal Science. 606.

https://digitalcommons.unl.edu/animalscifacpub/606

This Article is brought to you for free and open access by the Animal Science Department at DigitalCommons@University of Nebraska - Lincoln. It has been accepted for inclusion in Faculty Papers and Publications in Animal Science by an authorized administrator of DigitalCommons@University of Nebraska - Lincoln. 


\section{Authors}

F. W. Harrelson, Matt K. Luebbe, N. F. Meyer, Galen E. Erickson, Terry J. Klopfenstein, David S. Jackson, and W. A. Fithian 


\title{
Influence of corn hybrid and processing method on nutrient digestibility, finishing performance, and carcass characteristics ${ }^{1}$
}

\author{
F. W. Harrelson, ${ }^{* 2}$ M. K. Luebbe, ${ }^{*}$ N. F. Meyer, ${ }^{*}$ G. E. Erickson, ${ }^{* 3}$ T. J. Klopfenstein, ${ }^{*}$ \\ D. S. Jackson, $\dagger$ and W. A. Fithian $\ddagger$ \\ *Department of Animal Science, and $\dagger$ Department of Food Science and Technology, University of Nebraska, \\ Lincoln 68583; and $\ddagger$ Golden Harvest Seeds, Waterloo, NE 68069
}

\begin{abstract}
A finishing trial and a digestion trial were conducted to evaluate the effects of corn hybrid and processing method on nutrient digestibility, finishing performance, and carcass characteristics. A $2 \times 5$ factorial arrangement of treatments was used for both trials. Factors included 2 processing methods, dryrolled (DRC) or high-moisture (HMC), and 5 commercially available corn hybrids. The finishing trial (Exp. 1) utilized 475 yearling steers $(379 \pm 15 \mathrm{~kg}$ initial $\mathrm{BW})$, stratified by BW into 2 blocks then assigned randomly to 1 of 60 pens ( 8 steers/pen). Treatments were assigned randomly to pens with 6 pens/treatment. Diets consisted of $67.5 \%$ corn (each hybrid processed as DRC or HMC), $20 \%$ wet corn gluten feed, $7.5 \%$ alfalfa hay, and 5\% supplement. The digestion trial (Exp. 2) used 2 ruminally and duodenally fistulated Holstein steers (560 kg of BW) and the mobile bag technique. Bags were ruminally incubated for $22 \mathrm{~h}$. For total tract digestibility, bags were subjected to a simulated abomasal pepsin digestion, inserted into the duodenum, and col-
\end{abstract}

lected in the feces. No significant interactions between corn hybrid and processing method were observed in Exp. 1; therefore, only main effects are presented. Feeding HMC decreased $(P<0.01)$ DMI and increased $(P$ $<0.01)$ G:F compared with cattle fed DRC. Hybrid tended to affect $(P=0.12) \mathrm{G}: \mathrm{F}$, but did not affect $(P$ $>0.36)$ any other variable. For Exp. 2, feeding HMC increased $(P<0.01) \mathrm{DM}$ and starch digestibility compared with DRC, but to varying degrees depending on the hybrid. Correlating the results of the 2 trials across processing methods, strong relationships were observed between G:F and postruminal starch digestibility ( $\mathrm{r}$ $=0.84)$ and total-tract starch digestibility $(\mathrm{r}=0.73)$. When evaluated within processing method, these relationships weakened and were not significant. The results of these trials indicate that processing method had a larger effect on performance and digestibility than hybrid, and no interaction was observed between processing method and hybrid, suggesting hybrid effects were consistent across processing methods.

Key words: corn, digestibility, finishing cattle, hybrid, processing

(C)2009 American Society of Animal Science. All rights reserved.

J. Anim. Sci. 2009. 87:2323-2332 doi:10.2527/jas.2008-1527

\section{INTRODUCTION}

Due to its energy value relative to cost and production variables, corn is the most widely used grain source for finishing cattle (Galyean, 1996; Vasconcelos and Galyean, 2007). A large amount of research has been conducted to evaluate strategies to improve cattle performance when cattle are fed corn. Most scientific research has focused on corn processing (rolling, grind-

\footnotetext{
${ }^{1}$ A contribution of the University of Nebraska Agricultural Research Division, supported in part by funds provided through the Hatch Act.

${ }^{2}$ Present address: Department of Animal and Range Sciences, New Mexico State University, Las Cruces 88003.

${ }^{3}$ Corresponding author: geericks@unlnotes.unl.edu

Received September 29, 2008.

Accepted March 9, 2009.
}

ing, flaking, or ensiling) effects on finishing performance (Owens et al., 1997; Dew et al., 2003).

Recent research has focused on other ways to improve cattle efficiency when feeding corn. Corn hybrid and kernel characteristics have been shown to influence performance and digestibility (Philippeau et al., 1998; Jaeger et al., 2006). Jaeger et al. (2006) found that hybrids with greater 1,000-kernel weights and a larger proportion of soft endosperm fed as dry-rolled corn (DRC) increased G:F when compared with lesser kernel weight or harder endosperm. Flinty or harder hybrids were also found to have a decreased rate of starch degradation (Philippeau et al., 1998).

A limited amount of research has evaluated performance and digestibility differences when processing method and hybrid effects are combined. Macken et al. (2003) found that hybrids with a floury endosperm were more efficiently utilized compared with those with 
a flinty endosperm when fed as DRC. When these same hybrid types were fed as high-moisture corn (HMC), no difference in $\mathrm{G}: \mathrm{F}$ was observed between them. In a more recent study, Corona et al. (2006) found similar results when comparing DRC and steam-flaked corn. They found that flaking hybrids eliminated differences between harder and softer hybrids observed within DRC. Utilizing only HMC, Szasz et al. (2007) found that more vitreous hybrids were more digestible than less vitreous hybrids, due mostly to an increase in postruminal starch digestibility, which is in disagreement with previous research utilizing DRC (Corona et al., 2006).

The objectives of these 2 experiments were to determine the influence of corn hybrid, processing method as DRC or HMC, and hybrid $\times$ processing method interactions on finishing performance, carcass characteristics, and nutrient digestibility.

\section{MATERIALS AND METHODS}

The University of Nebraska's Institutional Animal Care and Use Committee approved all procedures and guidelines for animal experiments before this research.

\section{Grain Production}

Five commercially available corn hybrids, H-8803Bt, H-8562, H-9230Bt, H-9485Bt (Golden Harvest Seeds, Waterloo, NE), and 33P67 (Pioneer Hybrids, Johnston, IA) were grown in 2 fields under similar irrigated conditions at the University of Nebraska's Agricultural Research and Development Center (near Mead, NE). These hybrids were chosen based on previous research conducted at the University of Nebraska representing a wide range in 1,000 kernel weight and hardness, as well as previous research utilizing 3 (33P $67, \mathrm{H}-9230 \mathrm{Bt}$, and H-8562) of these hybrids (Jaeger et al., 2006; Luebbe et al., 2009). Hybrids were identity preserved throughout the growing season and harvested in early September (HMC) or early October (DRC). Corn ensiled as highmoisture was rolled, bagged, and stored in separate, identity-preserved ensiling bags until the conclusion of the trial. The HMC was stored for approximately 8 mo before trial initiation (September until May). Whole dry corn was stored in separate bins and rolled at delivery before feeding. Dry-rolled corn was stored in commodity bays. Weekly samples of each corn treatment were collected and frozen for further analysis at the conclusion of the trial. Crude protein content of corn samples was determined using a combustion-method $\mathrm{N}$ analyzer (Leco FP-528, Leco Corp., St. Joseph, MO) according to the AOAC (1995) procedure. Particle size determination was conducted using approximately 100 $\mathrm{g}$ (as-is basis) of each corn sample. United States Bureau of Standards (USBS) sieves \#4 $(4,750 \mu \mathrm{m})$, \#6 $(3,350 \mu \mathrm{m}), \# 12(1,700 \mu \mathrm{m})$, and \#30 $(600 \mu \mathrm{m})$ were utilized for determination of the geometric mean diameter $(\mu \mathrm{m})$ and geometric SD for each sample. The geometric mean diameter and the geometric SD were calculated as described by Behnke (1994). The USBS sieves were placed on a Fritsch Analysette sieving device (model 8751, Fritsch-GMbH, Idar-Oberstein, Germany) in the following order, from top to bottom, \#4, $\# 6$, \#12, and \#30. Samples were sieved for 10-min after which time the amount of sample on each screen was weighed similar to procedures outlined by Luebbe et al. (2009). Samples were analyzed in duplicate.

\section{Kernel Characteristics}

Corn samples (whole) were taken from truck loads delivered to the mill for rolling. Samples were sieved to remove cracked kernels and other debris to obtain whole kernel samples. Using a commercial seed counter (Seedburo Equipment Co., Chicago, IL), 1,000 whole kernels were counted and weighed. This air-dry kernel weight was analyzed in duplicate for each sample and then adjusted to a DM kernel weight, after DM analysis for 1,000-kernel weight.

Stenvert hardness tests were also conducted, in duplicate, on each sample. Twenty-gram samples were ground through a microhammermill (Micro Hammer Mill V, Glen Mills Inc., Maywood, NJ) beginning at $3,600 \mathrm{rpm}$ and equipped with a 2 -mm screen. Collected measurements were grinding time, reduction in hammermill speed at maximum grinding power, height $(\mathrm{cm})$ of soft endosperm particles, height $(\mathrm{cm})$ of entire ground sample, and weight of hard endosperm recovered over a US\#40 $(425 \mu \mathrm{m})$ sieve (Pomeranz et al., 1985). We designed an index utilizing the Stenvert measurements of time to grind and revolutions per minute to simplify the analysis of hard vs. soft endosperm types. This index was derived by taking the magnitude of change or decrease in revolutions per minute from 3,600 (beginning rpm) and multiplying this by the time to grind in seconds. By doing this calculation, we were able to have a measurement similar to an area under the curve for grinding difficulty.

\section{Exp. 1}

Crossbred yearling steers $(\mathrm{n}=480 ; 379 \pm 15 \mathrm{~kg}$ of $\mathrm{BW}$ ) were utilized in a randomized complete block design to evaluate the effect of corn hybrid, processing method, and corn hybrid $\times$ processing method interactions on finishing performance and carcass characteristics. Cattle were limit-fed at $2 \%$ of BW daily $(7.58 \mathrm{~kg}$ of a grass hay/sorghum silage ration) for $5 \mathrm{~d}$ before being weighed 2 consecutive days at trial initiation to obtain initial BW. Steers were stratified by BW into 2 blocks (light and heavy) and assigned randomly to 1 of 60 pens ( 8 steers/pen). Pens were assigned randomly to 1 of 10 treatments ( 6 pens/treatment). Treatments were arranged as a $2 \times 5$ factorial design with factors including 5 different hybrids (H-8803Bt, H-8562, H-9230Bt, H-9485Bt, and 33P67) and 2 processing methods (DRC and HMC). All diets were formulated to meet or exceed the NRC (1996) requirements for MP, Ca, P, K, and all 
other minerals. At study initiation, grain adaptation diets were fed by decreasing levels of alfalfa hay and increasing the corn hybrid for that treatment. Alfalfa hay was fed at $45,35,25$, and $15 \%$ for $3,4,7$, and $7 \mathrm{~d}$, respectively. Final diets consisted of $67.5 \%$ corn (variable tested), 20\% wet corn gluten feed (Sweet Bran, Cargill Inc., Blair, NE), $7.5 \%$ alfalfa hay, and $5 \%$ supplement (DM basis). Corn gluten feed was added to the diet to limit digestive upsets as discussed by Krehbiel et al. (1995). This approach of using wet corn gluten feed was similar to Jaeger et al. (2006) so that ruminal acidosis is minimized in hybrids with a rapid rate of starch digestion and when fed as HMC. Diets were formulated for $13.3 \% \mathrm{CP}$ in the ration, using the least $\mathrm{CP}$ value of any corn (i.e., $8.9 \% \mathrm{CP}$ ) to eliminate differences in performance being attributed to protein; however, hybrids ranged from 8.9 to $10.3 \% \mathrm{CP}$. Therefore, requirements for degradable intake protein and metabolizable protein were met for all treatments (NRC, 1996). This approach is similar to previous studies evaluating differences in hybrids (Erickson et al., 2003; Jaeger et al., 2006). The supplement, which was identical across treatments, provided $1.35 \%$ limestone, $0.44 \%$ urea, $0.30 \%$ salt, $0.05 \%$ trace mineral premix, and $0.015 \%$ vitamin premix (\% of diet DM) and was formulated to provide $90 \mathrm{mg} / \mathrm{steer}$ daily of Tylan (Elanco Animal Health, Greenfield, IN) and $320 \mathrm{mg} /$ steer daily of Rumensin (Elanco Animal Health).

Steers were fed once daily $(0700 \mathrm{~h})$ and were allowed ad libitum access to feed and water throughout the trial. Bunks were assessed to minimize excess feed, and feed refusals were removed as needed. On d 22, cattle were implanted with Revalor S (Intervet Inc., Millsboro, DE) and fed $127 \mathrm{~d}$ (heavy block) or $134 \mathrm{~d}$ (light block). Cattle were weighed the morning of shipping, and loaded out in the early evening. All cattle were harvested at a commercial abattoir (Greater Omaha, Omaha, NE) with the liver abscess scores and HCW collected on the day of harvest. After a 48-h chill, 12thrib fat thickness, LM area, KPH, and USDA marbling scores were collected. The USDA yield grades were calculated using the formula of Boggs et al. (1998).

To limit gut-fill variation, HCW were adjusted to a common $63 \%$ dress to calculate final BW. These adjusted BW were used to calculate ADG and G:F.

\section{Exp. 2}

Two ruminally and duodenally fistulated Holstein steers (560 kg of BW) were utilized in a digestion trial to evaluate the effect of corn hybrid, processing method, and hybrid $\times$ processing method interactions on site and extent of digestion using the mobile bag technique (Voigt et al., 1985; Haugen et al., 2006; Loveday et al., 2006). Two steers are sufficient for in situ (Vanzant et al., 1998) and the mobile bag technique (NRC, 2001). This experiment was initiated approximately 60 $\mathrm{d}$ after the beginning of the finishing study; therefore, corn samples were representative of Exp. 1. Steers were fed a diet consisting of $26.3 \%$ DRC, $26.3 \%$ HMC, $35 \%$ wet corn gluten feed (Sweet Bran), 7.5\% alfalfa hay, and $5 \%$ supplement (DM basis) while the mobile bags were incubated. The supplement was the same supplement used for Exp 1. Because this trial was a digestion study and to ensure that digestive upsets and feed intake depression would not be an issue for the fistulated steers, wet corn gluten feed inclusion in the basal diet was increased from 20 to $35 \%$. Steers were fed once daily $(0700 \mathrm{~h})$ with ad libitum access to feed and water throughout the trial. Feed refusals were removed daily. Steers were housed in individual pens on weeks when no bags were incubated, and placed in stanchions $24 \mathrm{~h}$ before the first day of insertions.

Corn samples utilized for Exp. 2 were composites of the first 6 weekly feed samples from Exp. 1. Each sample was ground through a Thomas-Wiley mill No. 4 to simulate mastication (6.35-mm screen) adapted from the procedure discussed by Simon (2001). Dry-rolled corn samples were directly ground and high-moisture samples were freeze ground using dry ice. A 2-g sample $(\mathrm{DM})$ of each sample was placed in $5 \times 10 \mathrm{~cm}$ Dacron bags $(53-\mu \mathrm{m}$ pore size; Ankom, Fairport, NY) for incubation. Each bag was heat-sealed before incubation. For ruminal digestibility, 4 bags/feed were incubated per steer. For postruminal and total tract digestibility measurements, 6 bags/feed were inserted per steer.

All bags were ruminally incubated for $22 \mathrm{~h}$, based on a $75 \%$ mean retention time for a $3.44 \% / \mathrm{h}$ passage rate (Shain et al., 1999). Preincubation within the rumen has been shown to improve postruminal starch digestion due to increased availability of ruminal undegraded starch by enzymatic digestion in the small intestine (Norberg et al., 2007). After ruminal incubation, postruminal bags were thawed and incubated in a pepsin and $\mathrm{HCl}$ solution ( $1 \mathrm{~g}$ of pepsin/L of $0.01 \mathrm{M}$ $\mathrm{HCl}$ ) at $37^{\circ} \mathrm{C}$ for $3 \mathrm{~h}$ to simulate abomasal digestion. Postruminal bags were rolled and placed in the duodenal fistula one at a time beginning at approximately $1700 \mathrm{~h}$. Bags were inserted every 5 min allowing for the movement of the previous bags into the intestines and to avoid compaction. Eight bags were incubated per day within a 4-d sampling week. Bags were collected in the feces, generally within $24 \mathrm{~h}$ postinsertion. Bags not collected within $48 \mathrm{~h}$ postinsertion were considered missing data points. Once collected, bags were frozen until the conclusion of the trial.

At the conclusion of the trial, bags were thawed, machine washed with five 3-min cycles, consisting of 1-min agitation and 2-min spin (Whittet et al., 2003). Bags were then rinsed in distilled water forcing all residues to the bottom, rolled, and placed in a $60^{\circ} \mathrm{C}$ forced air oven for $48 \mathrm{~h}$. After drying, bags were removed from the ovens, cooled, and weighed to determine DM disappearance. Bags were then composited within animal and sampled across days before starch analysis. Procedures used for the mobile bag technique were similar to those outlined by Haugen et al. (2006) and Luebbe et al. (2009). 
All samples were ground using a Cyclotec sample mill (No. 1093) with a 1-mm screen for starch analysis. Total starch content was measured using the Megazyme (Megazyme International, Co. Wicklow, Ireland) procedure. In this procedure, heat is used to partially hydrolyze and then totally solubilize the starch molecules. Next, the starch dextrins are quantitatively hydrolyzed to glucose by amyloglucosidase, and a coloring reagent is added to measure the amount of glucose via absorbance. The absorbance of samples was analyzed using a spectrophotometer (SPECTAmax 250, Molecular Devices, Sunnyvale, CA; absorbance of $510 \mathrm{~nm}$ ), and the amount of starch per sample was determined using a linear regression based on standards using pure corn starch. Starch digestibility was calculated as the difference between the amount of starch in the original sample and the amount in the residue.

\section{Statistical Analysis}

Kernel characteristic data were analyzed using the MIXED procedure (SAS Institute Inc., Cary, NC) with the model including only the fixed effect of hybrid as many of these techniques have to be performed on whole dry kernels. Therefore, kernel characteristic data cannot be evaluated separately for DRC and HMC. For Exp. 1, all performance and carcass data were analyzed using the MIXED procedure of SAS. Pen was used as the experimental unit, with block, hybrid, processing, and hybrid $\times$ processing interactions as fixed effects. If no significant interaction was observed $(P>0.10)$, then the main effects of hybrid and processing method were presented. If a significant interaction was observed $(P$ $<0.10)$, the simple effects were presented. For Exp. 2, all digestibility data were analyzed using the MIXED procedure of SAS with the model including hybrid, processing method, and hybrid $\times$ processing method interactions as fixed effects, and random effects of day and steer. The factorial arrangement of treatments was analyzed similar to Exp. 1. At the conclusion of both experiments, correlations were determined between kernel characteristics, G:F, and nutrient digestibilities. These relationships were analyzed using PROC CORR of SAS with variables including G:F, all nutrient digestibilities, and all kernel characteristics, including the Stenvert area under the curve index. For all data analysis, significance was based on an $\alpha$ of 0.05 .

\section{RESULTS}

\section{Kernel Characteristics}

Harvest moistures, CP, starch, and particle size analysis are presented in Table 1. A significant hybrid $\times$ processing method interaction was observed for starch content, CP content, and particle size $(P<0.05)$. Kernel weight (Table 2) was affected by hybrid $(P<$ 0.01 ), with hybrids H-9485Bt and H-8562 having the heaviest 1,000-kernel weight. Hybrid H-8803Bt was the lightest, and H-9230Bt and 33P67 were intermediate for 1,000-kernel weight. Numerical differences between corn yields were observed, though statistics were not analyzed because the plot within field was not replicated to test yield differences among hybrids. Hybrids 33P67 and H-9485Bt yielded 13.7 and $13.3 \mathrm{t} / \mathrm{ha}$, respectively. Hybrid H-9230Bt had a yield of $12.0 \mathrm{t} / \mathrm{ha}$, with $\mathrm{H}-8803 \mathrm{Bt}$ and $\mathrm{H}-8562$ yielding 13.0 and $12.4 \mathrm{t} / \mathrm{ha}$, respectively. As expected, a fairly wide range was observed among hybrids for many kernel traits, especially the Stenvert soft height, total height, and soft height percentage, although none of these were significant for hybrid $(P>0.21)$.

\section{Exp. 1}

No significant hybrid $\times$ processing interactions $(P$ $>0.49$ ) were observed for any finishing performance or carcass characteristics, therefore the main effects of hybrid and processing method are presented. Processing method affected finishing performance and carcass characteristics (Table 3). Steers fed DRC had greater $(P<0.01)$ DMI compared with steers fed HMC. Daily BW gain was not affected $(P=0.18)$ by processing, but G:F was improved $(P<0.01) 5.2 \%$ for steers fed HMC compared with those fed DRC. Steers fed HMC had greater 12th-rib fat thickness $(P<0.01)$ compared with steers fed DRC. Also, steers fed HMC had a larger LM area $(P=0.05)$ compared with those fed DRC. The increase in fat thickness and LM area did not affect calculated USDA Yield grade, which was similar $(P=$ 0.26 ) for both processing methods.

No significant hybrid effects (Table 4) were observed for ADG $(P=0.69)$ or DMI $(P=0.92)$. There was a trend $(P=0.12)$ for a hybrid effect on G:F, with $\mathrm{H}$ $9485 \mathrm{Bt}$ being the most efficiently utilized (0.161), and $\mathrm{H}-8803 \mathrm{Bt}$ being the least efficiently (0.155) used hybrid. Hybrids H-8562, H-9230Bt, and 33P67 were intermediate $(0.159,0.157$, and 0.156 , respectively).

Based on previous research (Macken et al., 2003; Szasz et al., 2007; Luebbe et al., 2009), we expected an interaction between hybrid and processing method. However, no interactions were observed. We did observe improved G:F for all hybrids when processed as HMC compared with DRC (Table 5). The greatest improvement in efficiency when calculated as the relative difference between the G:F of cattle fed HMC compared with DRC was observed for H-8803Bt (8.53\%), with the least improvement for 33P67 (2.26\%). This relative change from HMC to DRC was intermediate for hybrids H-9230Bt, H-8562, and H-9485Bt (5.65, 4.82, and $4.25 \%$, respectively).

\section{Exp. 2}

A significant interaction between hybrid and processing method was observed for ruminal, postruminal, and total-tract starch digestibility, as well as ruminal and total-tract DM digestibility (DMD); therefore, only 
simple effects are presented. No interaction between hybrid and processing method was observed for postruminal DMD. Ruminal DMD (Table 6) was greatest for hybrid $\mathrm{H}-9230 \mathrm{Bt}$ fed as HMC (68.0\%) and was the least for the same hybrid fed as DRC (37.9\%). A 22 to $80 \%$ improvement in ruminal DMD was observed within hybrids when processed as HMC compared with DRC.

For ruminal starch digestibility, H-9230Bt HMC was the most digestible (76.1\%), with $\mathrm{H}-8803 \mathrm{Bt}$ DRC being the least digestible (35.4\%). Hybrid H-8562 was improved the most $(99.6 \%)$ by processing as HMC.

Postruminal DMD was significantly increased $(P<$ 0.01 ) when hybrids were processed as HMC compared with DRC (65.3 vs. $57.7 \%$ ). Hybrids were significantly $(P<0.01)$ different in postruminal DMD with hybrids H-8562 (65.2\%) and 33P67 (65.3\%) being the most digestible. Hybrid H-9485Bt (57.3\%) was the least digestible, with $\mathrm{H}-8803 \mathrm{Bt}(60.3 \%)$ and $\mathrm{H}-9230 \mathrm{Bt}$ (59.0\%) being intermediately digestible.

Hybrid H-8562 HMC had the greatest extent of digestion for starch entering the small intestine (91.1\%), whereas 33P67 DRC exhibited the least extensive postruminal starch digestion (53.6\%). The HMC improved digestion of starch entering the small intestine by 30 to $53 \%$ compared with DRC among hybrids.

The greatest extent of DM digestion, throughout the digestive tract, was observed for H-8562 HMC (88.4\%), whereas 33P67 DRC exhibited the least amount of DM digestion $(69.8 \%)$ throughout the digestive tract. Samples of DRC, among hybrids, were 9 to $21 \%$ less digestible for DM compared with those hybrids processed as HMC.

Total-tract starch digestibility was least for 33P 67 DRC (70.8\%) and greatest for H-8562 HMC (98.1\%). When hybrids were processed as HMC, starch was 16 to $32 \%$ more digestible throughout the entire digestive tract compared with being processed as DRC.

\section{Correlations Between Trials}

At the conclusion of both studies, correlations were analyzed between G:F, nutrient digestibilities, and kernel characteristics (Table 7). Kernel traits and nutrient digestibilities were only compared within DRC or HMC and not across processing method; therefore, these data are presented in Tables 8 and 9, respectively.

Across processing methods (Table 7), kernel weight was the only kernel characteristic with a significant $(P$ $<0.02$ ) correlation to $\mathrm{G}: \mathrm{F}$, and the relationship was strongly positive $(\mathrm{r}=0.94)$. Feed efficiency was also significantly $(P<0.01)$ correlated to all nutrient digestibilities across processing methods, but the correlation is likely due to processing method more so than hybrid (data not shown). The strongest relationships were observed for postruminal starch, total-tract starch, and total-tract DM ( $\mathrm{r}=0.86$ for all) digestibility. The weakest relationships, although still strong, were observed for ruminal and postruminal DMD $(r=0.78$ for

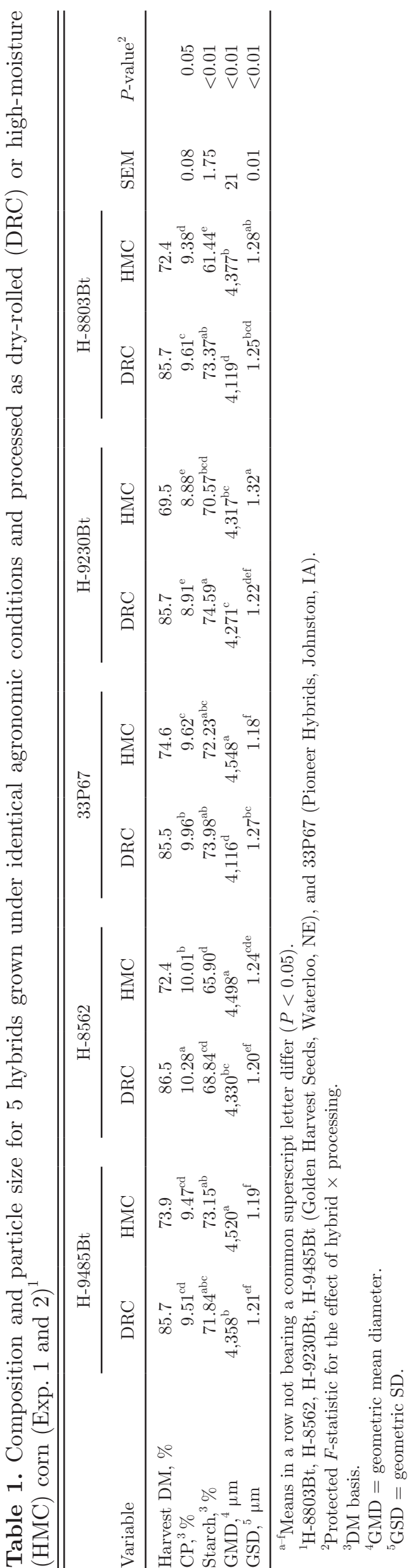


Table 2. Kernel characteristics for the 5 corn hybrids used in Exp. 1 and $2^{1}$

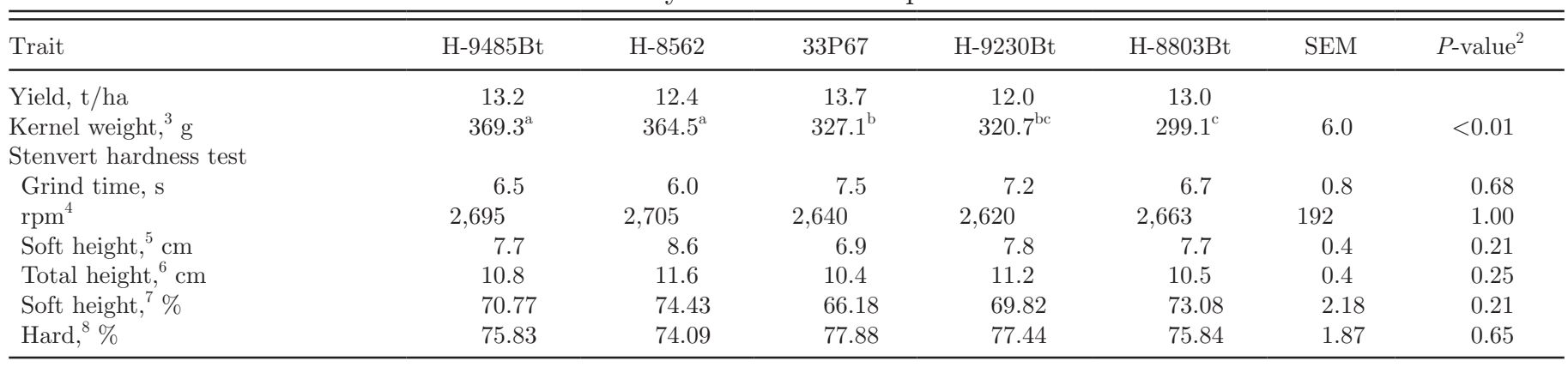

${ }^{\mathrm{a}-\mathrm{c}}$ Means within a row with unlike superscripts differ $(P<0.05)$.

${ }^{1} \mathrm{H}-8803 \mathrm{Bt}, \mathrm{H}-8562$, H-9230Bt, H-9485Bt (Golden Harvest Seeds, Waterloo, NE), and 33P67 (Pioneer Hybrids, Johnston, IA).

${ }^{2}$ Protected $F$-statistic for the effect of hybrid.

${ }^{3} 1,000$-kernel weight (DM).

${ }^{4}$ Least rpm of machine recorded from a beginning rpm of 3,600

${ }^{5}$ Height in cm of soft particle column in ground corn sample.

${ }^{6}$ Total height in $\mathrm{cm}$, ground sample column.

${ }^{7}$ Percentage of soft to coarse particles based on soft column height over total column height.

${ }^{8}$ Percentage of coarse particles remaining on $425-\mu \mathrm{m}$ screen after sieving.

Table 3. Main effect of corn processing method on finishing performance and carcass characteristics in Exp. 1 (30 pens per treatment mean $)^{1}$

\begin{tabular}{|c|c|c|c|c|}
\hline Variable & HMC & DRC & SEM & $P$-value ${ }^{2}$ \\
\hline \multicolumn{5}{|l|}{ Feedlot performance } \\
\hline Initial BW, $\mathrm{kg}$ & 380 & 379 & 1 & 0.88 \\
\hline Final BW, kg & 618 & 613 & 2 & 0.17 \\
\hline $\mathrm{ADG}, \mathrm{kg}$ & 1.82 & 1.79 & 0.02 & 0.18 \\
\hline DMI, $\mathrm{kg} / \mathrm{d}$ & 11.29 & 11.65 & 0.08 & $<0.01$ \\
\hline $\mathrm{G}: \mathrm{F}$ & 0.162 & 0.154 & 0.001 & $<0.01$ \\
\hline \multicolumn{5}{|l|}{ Carcass characteristic } \\
\hline $\mathrm{HCW}, \mathrm{kg}$ & 389 & 386 & 2 & 0.17 \\
\hline Marbling score ${ }^{3}$ & 517 & 507 & 5 & 0.21 \\
\hline 12th-rib fat thickness, cm & 1.38 & 1.29 & 0.02 & $<0.01$ \\
\hline $\mathrm{LM}$ area, $\mathrm{cm}^{2}$ & 86.5 & 85.1 & 0.5 & 0.05 \\
\hline Yield grade ${ }^{4}$ & 3.23 & 3.17 & 0.04 & 0.27 \\
\hline
\end{tabular}

\footnotetext{
${ }^{1} \mathrm{HMC}=$ high-moisture corn; DRC $=$ dry-rolled corn.

${ }^{2}$ Protected $F$-statistic for the effect of processing method.

${ }^{3}$ USDA marbling score: $450=$ Slight $^{50}, 500=$ Small $^{00}$, etc.

${ }^{4} \mathrm{USDA}$ Yield grade $=2.5+(2.5 \times 12$ th-rib fat thickness $)+(0.2 \times \mathrm{KPH} \%)+(0.0038 \times \mathrm{HCW})-(0.32 \times$ LM area).
}

Table 4. Main effect of corn hybrid on finishing performance and carcass characteristics in Exp. 1 (12 pens per treatment mean $)^{1}$

\begin{tabular}{|c|c|c|c|c|c|c|c|}
\hline Variable & H-9485Bt & H-8562 & $33 \mathrm{P} 67$ & $\mathrm{H}-9230 \mathrm{Bt}$ & $\mathrm{H}-8803 \mathrm{Bt}$ & SEM & $P$-value ${ }^{2}$ \\
\hline Initial BW, $\mathrm{kg}$ & 379 & 380 & 379 & 381 & 379 & 1 & 0.45 \\
\hline $\mathrm{ADG}, \mathrm{kg}$ & 1.84 & 1.82 & 1.80 & 1.79 & 1.79 & 0.01 & 0.69 \\
\hline DMI, $\mathrm{kg} / \mathrm{d}$ & 11.42 & 11.43 & 11.49 & 11.45 & 11.57 & 0.12 & 0.92 \\
\hline $\mathrm{G}: \mathrm{F}$ & 0.161 & 0.159 & 0.156 & 0.157 & 0.155 & 0.002 & 0.12 \\
\hline Marbling score ${ }^{3}$ & 506 & 514 & 512 & 512 & 515 & 9 & 0.95 \\
\hline 12th-rib fat thickness, $\mathrm{cm}$ & 1.32 & 1.36 & 1.35 & 1.33 & 1.31 & 0.03 & 0.79 \\
\hline LM area, $\mathrm{cm}^{2}$ & 86.2 & 85.2 & 86.6 & 85.8 & 84.9 & 0.8 & 0.36 \\
\hline Yield grade $^{4}$ & 3.17 & 3.24 & 3.18 & 3.20 & 3.22 & 0.06 & 0.88 \\
\hline
\end{tabular}

${ }^{1} \mathrm{H}-8803 \mathrm{Bt}, \mathrm{H}-8562$, H-9230Bt, H-9485Bt (Golden Harvest Seeds, Waterloo, NE), and 33P67 (Pioneer Hybrids, Johnston, IA).

${ }^{2}$ Protected $F$-statistic for the effect of hybrid.

${ }^{3}$ USDA marbling score: $450=$ Slight $^{50}, 500=$ Small $^{00}$, etc.

${ }^{4}$ USDA Yield grade $=2.5+(2.5 \times 12$ th-rib fat thickness $)+(0.2 \times \mathrm{KPH} \%)+(0.0038 \times \mathrm{HCW})-(0.32 \times \mathrm{LM}$ area $)$. 
Table 5. Simple effects of processing method within corn hybrid on finishing performance in Exp. 1 (6 pens per treatment mean $)^{1}$

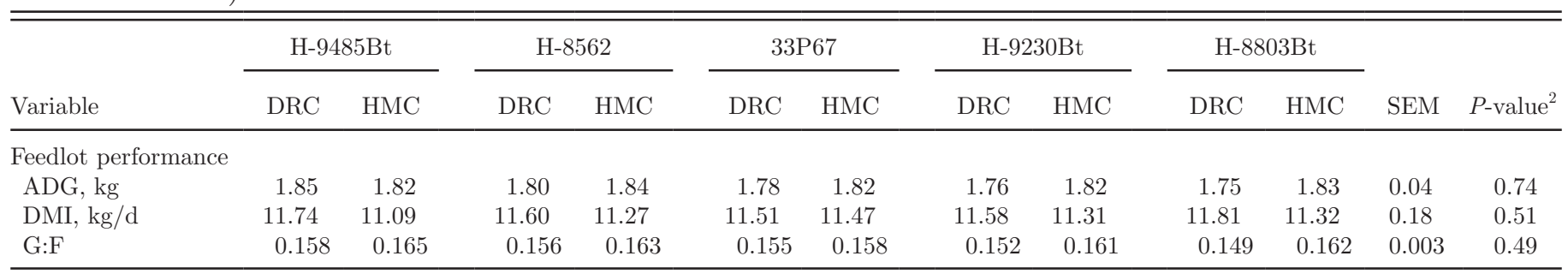

${ }^{1} \mathrm{DRC}=$ dry-rolled corn; HMC = high-moisture corn. H-8803Bt, H-8562, H-9230Bt, H-9485Bt (Golden Harvest Seeds, Waterloo, NE), and 33P67 (Pioneer Hybrids, Johnston, IA).

${ }^{2}$ Protected $F$-statistic for the effect of hybrid $\times$ processing.

Table 6. Simple effects of processing method within corn hybrid on nutrient digestibility in Exp. $2^{1}$

\begin{tabular}{|c|c|c|c|c|c|c|c|c|c|c|c|c|}
\hline \multirow[b]{2}{*}{ Variable } & \multicolumn{2}{|c|}{$\mathrm{H}-9485 \mathrm{Bt}$} & \multicolumn{2}{|c|}{ H- 8562} & \multicolumn{2}{|c|}{$33 \mathrm{P} 67$} & \multicolumn{2}{|c|}{ H-9230Bt } & \multicolumn{2}{|c|}{ H-8803Bt } & \multirow[b]{2}{*}{ SEM } & \multirow[b]{2}{*}{$P$-value ${ }^{2}$} \\
\hline & DRC & $\mathrm{HMC}$ & DRC & $\mathrm{HMC}$ & DRC & HMC & DRC & HMC & DRC & HMC & & \\
\hline Ruminal STD ${ }^{4}$ & $37.2^{\mathrm{d}}$ & $52.7^{\mathrm{c}}$ & $35.6^{\mathrm{d}}$ & $71.1^{\mathrm{a}}$ & $36.7^{\mathrm{d}}$ & $60.8^{\mathrm{bc}}$ & $38.4^{\mathrm{d}}$ & $76.1^{\mathrm{a}}$ & $35.4^{\mathrm{d}}$ & $68.8^{\mathrm{ab}}$ & 3.94 & $<0.01$ \\
\hline Postruminal DMD ${ }^{5}$ & 62.1 & 68.5 & 62.9 & 67.6 & 52.2 & 62.4 & 56.6 & 61.3 & 54.2 & 66.4 & 7.0 & 0.28 \\
\hline Postruminal STD ${ }^{5}$ & $66.7^{\mathrm{d}}$ & $82.6^{\mathrm{b}}$ & $65.4^{\mathrm{de}}$ & $91.1^{\mathrm{a}}$ & $53.6^{\mathrm{g}}$ & $76.9^{\mathrm{c}}$ & $56.6^{\mathrm{fg}}$ & $86.5^{\mathrm{ab}}$ & $60.2^{\mathrm{ef}}$ & $88.5^{\mathrm{a}}$ & 7.47 & $<0.01$ \\
\hline
\end{tabular}

\footnotetext{
${ }^{\mathrm{a}-\mathrm{g}}$ Means within a row with unlike superscripts differ $(P<0.05)$.

${ }^{1} \mathrm{DRC}=$ dry-rolled corn; HMC = high-moisture corn. H-8803Bt, H-8562, H-9230Bt, H-9485Bt (Golden Harvest Seeds, Waterloo, NE), and 33P67 (Pioneer Hybrids, Johnston, IA).

${ }^{2} P$-value for interaction of hybrid $\times$ processing method.

${ }^{3} \mathrm{DMD}=\mathrm{DM}$ digestibility.

${ }^{4} \mathrm{STD}=$ starch digestibility.

${ }^{5}$ Expressed as percentage of nutrient entering the intestines.
}

Table 7. Correlations between kernel characteristics and G:F across processing methods

\begin{tabular}{|c|c|c|c|c|c|c|c|c|c|}
\hline Trait $^{1}$ & $\mathrm{G}: \mathrm{F}$ & Kern & Grind & $\mathrm{rpm}$ & SProx & Soht & Totht & Soht\% & Hard\% \\
\hline $\mathrm{G}: \mathrm{F}$ & 1.00 & & & & & & & & \\
\hline Kern & $0.94^{\mathrm{a}}$ & 1.00 & & & & & & & \\
\hline Grind & -0.57 & -0.59 & 1.00 & & & & & & \\
\hline $\mathrm{rpm}$ & 0.67 & 0.73 & $-0.90^{\mathrm{a}}$ & 1.00 & & & & & \\
\hline SProx & -0.60 & -0.62 & $0.98^{\mathrm{a}}$ & $-0.97^{\mathrm{a}}$ & 1.00 & & & & \\
\hline Soht & 0.43 & 0.43 & -0.87 & 0.60 & -0.75 & 1.00 & & & \\
\hline Totht & 0.48 & 0.52 & -0.61 & 0.35 & -0.46 & $0.88^{\mathrm{a}}$ & 1.00 & & \\
\hline Soht $\%$ & 0.23 & 0.19 & $-0.90^{\mathrm{a}}$ & 0.65 & -0.82 & $0.89^{\mathrm{a}}$ & 0.57 & 1.00 & \\
\hline Hard\% & -0.46 & -0.51 & $0.99^{\mathrm{a}}$ & $-0.89^{\mathrm{a}}$ & $0.97^{\mathrm{a}}$ & -0.86 & -0.59 & $-0.91^{\mathrm{a}}$ & 1.00 \\
\hline
\end{tabular}

\footnotetext{
${ }^{\mathrm{a}}$ Indicates correlation significantly different from zero $(P<0.05)$.

${ }^{1}$ Trait abbreviations: 1,000-kernel weight (Kern), Stenvert time to grind (Grind), Stenvert hardness index (SProx), Stenvert soft height (Soht), Stenvert total height (Totht), Stenvert soft height percentage (Soht\%), and Stenvert hard percentage (Hard\%).
} 

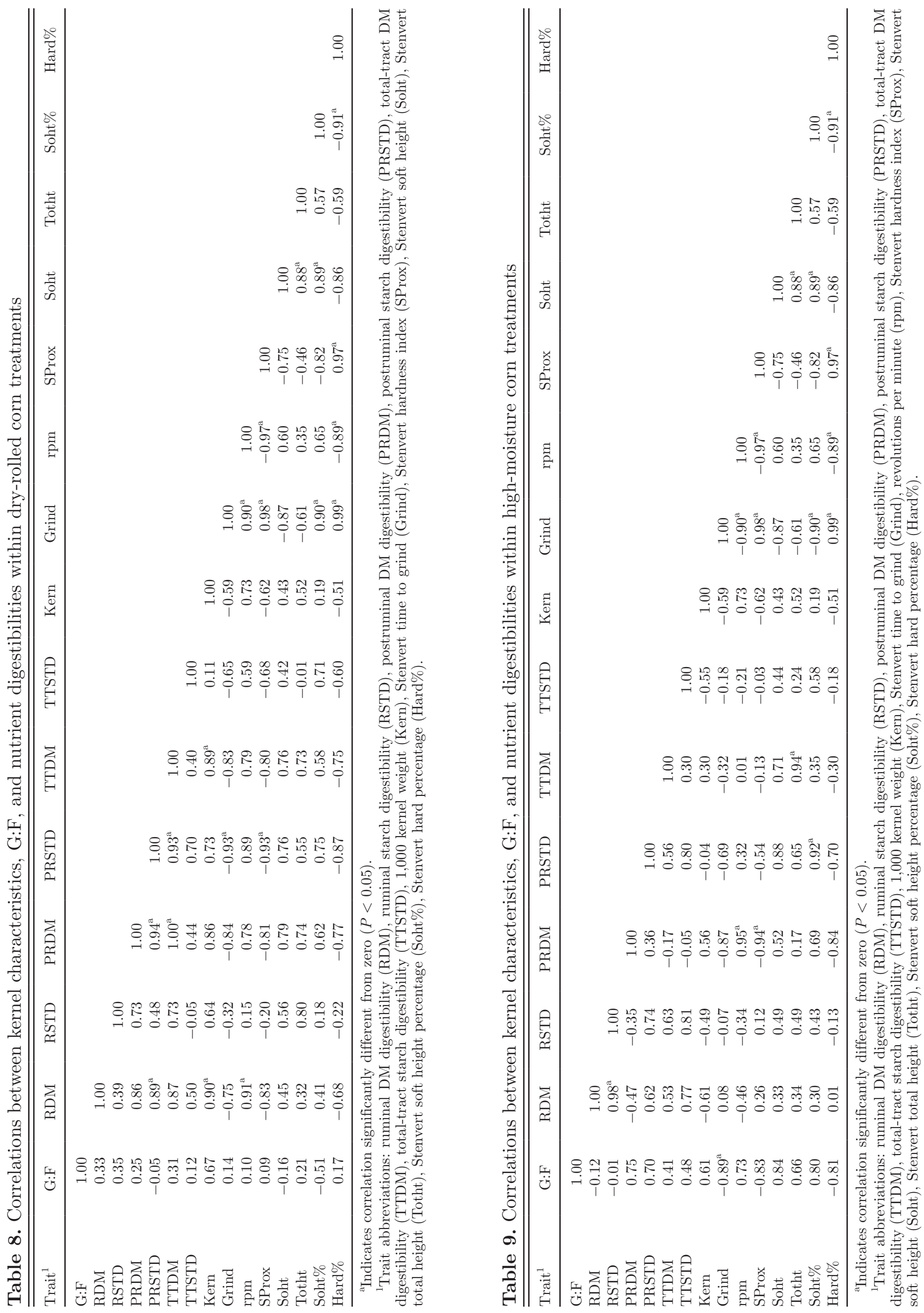
Table 10. Summary of 4 research trials utilizing hybrids H-8562, H-9230Bt, and 33P $67^{1}$

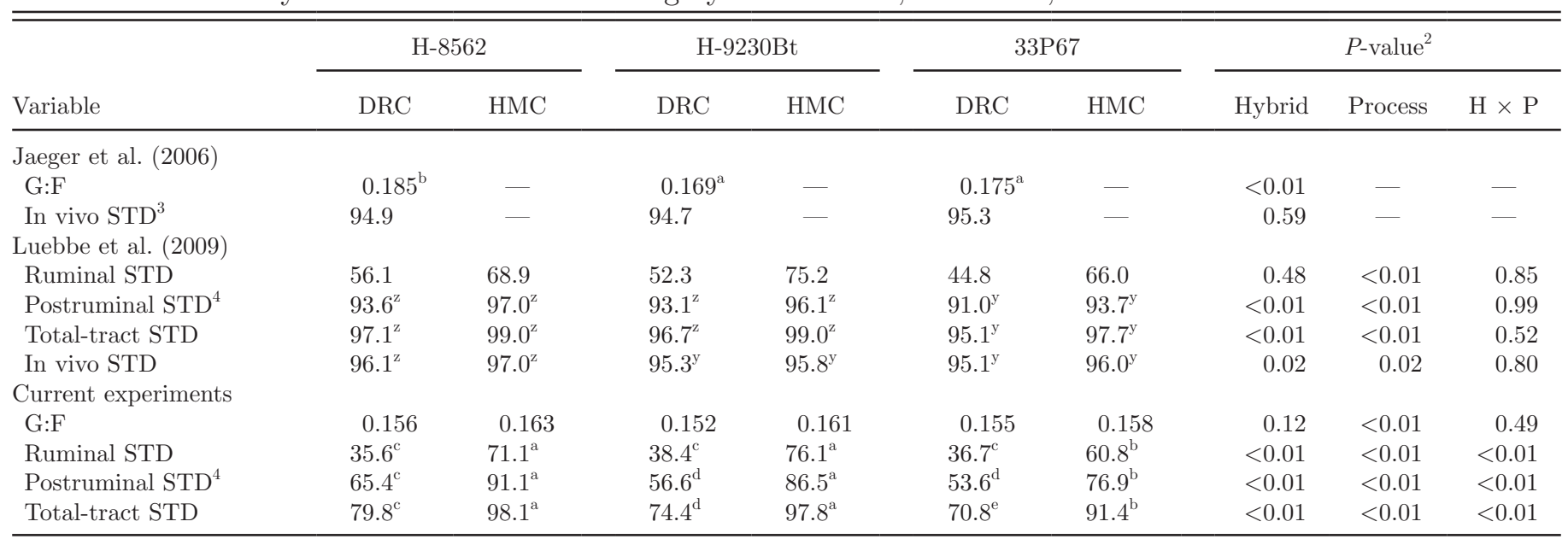

${ }^{\mathrm{a}-\mathrm{e}}$ Significant hybrid $\times$ processing method interaction. Means within a row with unlike superscripts differ $(P<0.05)$.

${ }^{\mathrm{y}, \mathrm{z}}$ Significant hybrid effect. Means within a row with unlike superscripts differ $(P<0.05)$.

${ }^{1}$ DRC $=$ dry-rolled corn; HMC = high-moisture corn. H-8562 and H-9230Bt (Golden Harvest Seeds, Waterloo, NE) and 33P67 (Pioneer Hybrids, Johnston, IA).

${ }^{2}$ Protected $F$-statistic for the effects of hybrid, processing method, and hybrid $(\mathrm{H}) \times$ processing $(\mathrm{P})$ method.

${ }^{3} \mathrm{STD}=$ starch digestibility.

${ }^{4}$ Postruminal STD expressed as percentage entering the duodenum.

both), whereas ruminal starch digestibility $(\mathrm{r}=0.80)$ was slightly greater.

Within DRC (Table 8), kernel weight was correlated with ruminal $(P<0.04, \mathrm{r}=0.90)$, postruminal $(P=$ $0.06, \mathrm{r}=0.86)$, and total-tract $(P=0.04, \mathrm{r}=0.89)$ DMD. The revolutions per minute were correlated with ruminal $\operatorname{DMD}(P=0.03, \mathrm{r}=0.91)$. Stenvert time to grind was negatively correlated with postruminal $(P=$ $0.07, \mathrm{r}=-0.84)$ and total-tract $(P=0.08, \mathrm{r}=-0.83)$ DMD. Both of these relationships indicated that harder kernels decrease digestibility.

Within HMC (Table 9), postruminal DMD was negatively correlated to Stenvert time to grind $(P=0.06$, $\mathrm{r}=-0.87)$ and Stenvert hard percentage $(P=0.08, \mathrm{r}$ $=-0.83)$ and positively correlated to revolutions per minute $(P=0.01, \mathrm{r}=0.95)$. Total-tract DMD was positively correlated to the Stenvert total height of ground sample $(P<0.02, \mathrm{r}=0.94)$.

\section{DISCUSSION}

A few studies have evaluated cattle performance differences due to hybrid and processing method. Ladely et al. (1995) evaluated 3 corn hybrids fed as DRC or early harvested HMC across 2 yr. They observed differences in G:F and ADG due to hybrid in yr 1, which corresponded to differences in rate of in vitro starch digestion. Using the same hybrids and similar agronomic practices in yr 2, they observed no differences in G:F or ADG due to hybrid; however, there were also minimal differences in in vitro starch digestion in yr 2. Performance was improved when cattle were fed HMC compared with being fed DRC in yr 2. We also observed no differences in performance due to hybrid, although processing method did affect cattle performance. Though we did not measure the rate of digestion, we did identify differences in digestibility (Exp. 2) of DM and starch. The results of Ladely et al. (1995) suggest that some physical characteristic of the corn kernel affects starch digestion and inherently cattle performance. Research evaluating physical characteristics and their effect on digestibility has had differing results. Philippeau et al. (1999) studied physical traits of corn and their relationship with in situ ruminal starch digestibility. Their study evaluated the physical characteristics of vitreousness, grinding energy, apparent and true densities, specific surface area, and 1,000-kernel weight using 8 denttype and 6 flint-type corn hybrids. They also evaluated the rate of DM and starch disappearance using an in situ trial. Though their study did not examine animal performance, they did identify some useful ways to predict starch digestibility, including a strong prediction based on vitreousness $\left(\mathrm{r}^{2}=0.89\right)$.

We did not observe a strong relationship between 1,000-kernel weight and ruminal starch digestibility $(P=0.25, \mathrm{r}=0.64$ for DRC; $P=0.41, \mathrm{r}=-0.49$ for HMC). However, we did observe that kernel weight was related to ruminal DMD for DRC $(P=0.04, \mathrm{r}=$ $0.90)$.

In a recent study evaluating corn hybrid effects when feeding DRC (Jaeger et al., 2006), relationships were observed between G:F and kernel characteristics. These researchers observed that 1,000-kernel weight was highly correlated $(P<0.05, \mathrm{r}=0.81)$ to $\mathrm{G}: \mathrm{F}$. In this study, we observed a correlation between G:F and kernel weight across hybrids $(P=0.02, \mathrm{r}=0.94)$. Jaeger et al. (2006) evaluated 3 of the same hybrids used in Exp. 1 and Exp. 2. For many kernel traits, the 3 hybrids (H9230Bt, H-8562, and 33P67) followed similar patterns between studies. Feed efficiency also followed a similar 
pattern with cattle fed H-8562 having the greatest G:F of the 3 and H-9230Bt and 33P67 being similar.

Luebbe et al. (2009) utilized the same 3 hybrids (H8562, H-9230Bt, and 33P67) in digestion and mobile bag experiments to evaluate the site and extent of digestion affected by hybrid and processing method. Four experiments with different methodology have been conducted with these 3 hybrids, and these results are compared in Table 10.

The results of this study suggest that processing method can affect finishing cattle performance. An interaction between hybrid and processing method may affect site and extent of digestibility, though this interaction was not observed in cattle performance. The relationship between feed efficiency and 1,000 kernel weight indicates that cattle fed hybrids with greater kernel weights are more efficient than those cattle fed hybrids with decreased kernel weights. Because kernel weight is a quick and simple test, it could be used to differentiate corn hybrids in terms of feeding value for finishing cattle. It does appear that processing method has a larger effect than hybrid on feedlot cattle performance.

\section{LITERATURE CITED}

AOAC. 1995. Methods of Analysis. 14th ed. Assoc. Off. Anal. Chem., Arlington, VA.

Behnke, K. C. 1994. Feed Manufacturing Technology IV. American Feed Industry Association Inc., Arlington, VA.

Boggs, D. L., R. A. Merkel, and M. E. Doumit. 1998. Livestock and Carcasses: An Integrated Approach to Evaluation, Grading, and Selection, 5th ed. Kendall/Hunt Publishing, Dubuque, IA.

Corona, L., F. N. Owens, and R. A. Zinn. 2006. Impact of corn vitreousness and processing on site and extent of digestion by feedlot cattle. J. Anim. Sci. 84:3020-3031.

Dew, P. F., M. S. Brown, N. A. Cole, and C. D. Drager. 2003. Effects of degree of corn processing on site and extent of digestion by beef steers. Pages 44-49 in Beef Cattle Res. Texas. Texas A \& M Univ., College Station.

Erickson, G. E., N. D. Robbins, J. J. Simon, L. L. Berger, T. J. Klopfenstein, E. P. Stanisiewski, and G. F. Hartnell. 2003. Effect of feeding glyphosate-tolerant (Roundup-Ready events GA21 or nk603) corn compared with reference hybrids on feedlot steer performance and carcass characteristics. J. Anim. Sci. 81:2600-2608.

Galyean, M. L. 1996. Protein levels in beef cattle finishing diets: Industry application, university research, and systems results. J. Anim. Sci. 74:2860-2870.

Haugen, H. L., S. K. Ivan, J. C. MacDonald, and T. J. Klopfenstein. 2006. Determination of undegradable intake protein digestibility of forages using the mobile nylon bag technique. J. Anim. Sci. 84:886-893.

Jaeger, S. L., M. K. Luebbe, C. N. Macken, G. E. Erickson, T. J. Klopfenstein, W. A. Fithian, and D. S. Jackson. 2006. Influence of corn hybrid traits on digestibility and efficiency of gain in feedlot cattle. J. Anim. Sci. 84:1790-1800.

Krehbiel, C. R., R. A. Stock, D. W. Herold, D. H. Shain, G. A. Ham, and J. E. Carulla. 1995. Feeding wet corn gluten feed to reduce subacute acidosis in cattle. J. Anim. Sci. 73:2931-2939.
Ladely, S. R., R. A. Stock, F. K. Goedeken, and R. P. Huffman. 1995. Effect of corn hybrid and grain processing method on rate of starch disappearance and performance of finishing cattle. J. Anim. Sci. 73:360-364.

Loveday, D. M., H. C. Block, P. A. Thacker, and J. J. McKinnon. 2006. Factors affecting the apparent intestinal (small and large) disappearance of dry matter and crude protein from rumen undegradable residues of various feeds determined using the mobile bag technique for cattle. Can. J. Anim. Sci. 86:419-428.

Luebbe, M. K., G. E. Erickson, T. J. Klopfenstein, and W. A. Fithian. 2009. Influence of corn hybrid traits and processing method on nutrient digestibility. Prof. Anim. Sci. In press.

Macken, C. N., G. E. Erickson, C. T. Milton, T. J. Klopfenstein, and H. Block. 2003. Effects of starch endosperm type and corn processing method on feedlot performance, nutrient digestibility, and ruminal fermentation of high-grain diets. Neb. Beef Rep. MP 80-A:32-34.

Norberg, E., H. Volden, and O. M. Harstad. 2007. Technical Note: Assessment of recovery site of mobile nylon bags for measuring ileal digestibility of starch in dairy cows. J. Dairy Sci. 90:418-421.

NRC. 1996. Nutrient Requirements of Beef Cattle. 7th ed. Natl. Acad. Press, Washington, DC.

NRC. 2001. Nutrient Requirements of Dairy Cattle. 7th ed. Natl. Acad. Press, Washington, DC.

Owens, F. N., D. S. Secrist, W. J. Hill, and D. R. Gill. 1997. The effect of grain source and grain processing on performance of feedlot cattle: A review. J. Anim. Sci. 75:868-879.

Philippeau, C., J. Landry, and B. Michalet-Doreau. 1998. Influence of the biochemical and physical characteristics of the maize grain on ruminal starch degradation. J. Agric. Food Chem. 46:4287-4291.

Philippeau, C., F. Le Deschault, and B. Michalet-Doreau. 1999. Relationship between ruminal starch degradation and the physical characteristics of corn grain. J. Anim. Sci. 77:238-243.

Pomeranz, Y., Z. Czuchajowska, C. R. Martin, and F. S. Lai. 1985. Determination of maize hardness by the Stenvert Hardness Tester. Cereal Chem. 62:108-112.

Shain, D. H., R. A. Stock, T. J. Klopfenstein, and D. W. Herold. 1999. The effect of forage source and particle size on finishing yearling steer performance and ruminal metabolism. J. Anim. Sci. 77:1082-1092.

Simon, J. J. 2001. Effects of particle size and mastication on starch digestion. MS Thesis. University of Nebraska, Lincoln.

Szasz, J. I., C. W. Hunt, P. A. Szasz, R. A. Weber, F. N. Owens, W. Kezar, and O. A. Turgeon. 2007. Influence of endosperm vitreousness and kernel moisture at harvest on site and extent of digestion of high-moisture grain by feedlot steers. J. Anim. Sci. 85:2214-2221.

Vanzant, E. S., R. C. Cochran, and E. C. Titgemeyer. 1998. Standardization of in situ techniques for ruminal feedstuff evaluation. J. Anim. Sci. 76:2717-2729.

Vasconcelos, J. T., and M. L. Galyean. 2007. Nutritional recommendations of feedlot consulting nutritionists: The 2007 Texas Tech University survey. J. Anim. Sci. 85:2772-2781.

Voigt, J., B. Piatkowski, H. Engelmann, and E. Rudolph. 1985. Measurement of the postruminal digestibility of crude protein by the bag technique in cows. Arch. Tierernaahr. Berlin 33:555-562.

Whittet, K. M., K. W. Creighton, K. J. Vander Pol, G. E. Erickson, and T. J. Klopfenstein. 2003. Influence of rinsing technique and sample size on in situ protein degradation. Nebraska Beef Report MP 80-A:86-88. Univ. Nebraska, Lincoln. 